Conition and neurocognition: effects of risperidone, olanzapine,

and haloperidol

Mark J. Sergi, Michael F. Green

Clifford Widmark, Christopher Reist,

Stephen Erhart, David L. Braff,

Kimmy S. Kee, Stephen R. Marder,

and Jim Mintz
1593 The Cognitive and Negative Symptoms in Schizophrenia Trial (CONSIST): the efficacy of glutamatergic agents for negative symptoms and cognitive impairments

Robert W. Buchanan, Daniel C. Javitt, Stephen R. Marder, Nina R. Schooler James M. Gold, Robert P. McMahon, Uriel Heresco-Levy, and WilliamT.Carpenter
1603 The role of dopamine in attentional and memory biases for emotiona information

Ayana A. Gibbs, Kris H., Naudts Edgar P. Spencer, and Anthony S. David

The American Journal of Psychiatry is

online at http: / /ajp. psychiatryonline.org

\title{
Advances in

\section{CONTENTS}

Editorial: Recovery: our common purpose? Glenn Roberts $\mathcal{E}$ Sheila Hollins

Cannabis use and psychosis: the origins and implications of an association John Macleod

Epidemiology: what it is and why it matters. Invited commentary on: Cannabis use and psychosis

Brendan D. Kelly

Off-label prescribing in psychiatric practice David S. Baldwin \& Nick Kosky

Why don't patients attend their appointments? Maintaining engagement with psychiatric services

Alex J. Mitchell and Thomas Selmes

Why do psychiatrists have difficulty disengaging with the out-patient clinic? Invited commentary on: Why don't patients attend their appointments? Helen Killaspy

Cognitive-behavioural therapy for obsessive-compulsive disorder David Veale

Recognising and managing antidepressant discontinuation symptoms Peter M. Haddad and Ian M. Anderson

The cognitive behavioural analysis system of psychotherapy: a new psychotherapy for chronic depression John S. Swan and Alastair M. Hull

The work patterns of consultant psychiatrists. Revisiting: How consultants manage their time Judith Harris

For further information on subscribing to this journal please contact:

Subscriptions Dept, Maney Publishing, Suite 1c, Joseph's Well, Hanover Walk, LEEDS LS3 1AB, UK.

Tel: +44 (0)113 243 2800. Fax: +44 (0)113 386 8178. Email: subscriptions@maney.co.uk Order online: www.maney.co.uk

For LIS orters: Maney Publishing North America, 875 Massachusetts Avenue, 7th Floor, Cambridge, MA ()2139, USA Tel: 8662975154 (toll free). Fax: +16173546875 . Email: maney@maneyusa.com 